\title{
Investigating the effect of role conflict and role ambiguity on employees' job stress: Articulating the role of work-family conflict
}

\author{
Iraj Soltani $^{\mathrm{a}}$, Sara Hajatpour ${ }^{\mathrm{b} *}$, Jalal Khorram ${ }^{\mathrm{b}}$ and Mohammad Hosein Nejati ${ }^{\mathrm{c}}$
}

\author{
${ }^{a}$ Manager of Teaching, Research and Development at Foolad Mobarakeh corporate and Assistant Professor of Islamic Azad University_Isfahan \\ Science \& Research Branch,Isfahan, Iran \\ ${ }^{b}$ PH.D student of Public management, Islamic Azad University_Isfahan Science \& Research Branch,Isfahan, Iran \\ ${ }^{c}$ Msc in public management, Islamic Azad University_Isfahan Science \& Research Branch,Isfahan, Iran
}

\section{CHRON I C LE A B T T A C T}

\section{Article history:}

Received March 12, 2013

Received in revised format

10 June 2013

Accepted 22 June 2013

Available online

June 252013

Keywords:

Role ambiguity

Role conflict

Work-family conflict

Job stress

\begin{abstract}
Psychologists and researchers of management sciences are of great interest in subject of stress and the major reason for this is its impact on psychological well-being and organizational consequences. They also recommend that preventing stress called destructive stress results from factors such as role ambiguity, role uncertainty, and organizational policies, and decreases both the individual and organizational performance. The purpose of this study is to investigate the effect of role conflict and role ambiguity on employees' job stress by explaining the role of work-family conflict. The statistical population of this study is comprised of 530 employees of Iran's central insurance. Using stratified random sampling and Cochran's formula, a sample of 118 employees was selected. We used a researcher-made questionnaire for data gathering. The Cronbach's alpha for this questionnaire was .88 and split-half reliability was .80 , which represents for a reliable questionnaire. Furthermore, we used content validity and confirmatory factor analysis to confirm the validity of questionnaire. Data analysis was accomplished by structural equation modeling using the LISREL software $v$ 8.7. Research results indicate that the effect of role ambiguity on work-family conflict is statistically significant ( $\mathrm{p}$-value $=62.40$ ). Furthermore, the effect of role ambiguity on job stress was confirmed with significance of 1.83 . On the other hand, the effect of role conflict on work-family conflict was not confirmed, because its significance value was negative. However, it was found that the job stress is influenced by role conflict ( $\mathrm{p}$-value $=2.35$ ). And finally, the effect of work-family conflict on job stress was confirmed with the number of .93 for its significance value.
\end{abstract}

\section{Introduction}

The job stress can be described as a feeling in which the individual cannot adjust his/her capabilities, resources, and demands with the job needs (Harrisons, 2005). The workplace stress or job stress appears when employees detect the workplace demands for adaptation and adjustment beyond their capabilities and resources. Many researches on job stress have concentrated on such aspects of the

*Corresponding author. Tel: +989175670929

E-mail addresses: khorram2010@gmail.com (S. Hajatpour) 
workplace, which may cause the employees to be stressed. These aspects are factors that act as stressors (Hit et al., 2006). The job stressors are divided into two types: organizational stressors and managerial stressors (Human Resource Management, 2005; Ivancevich et al., 2001).

The organizational stressors are comprised of job flow components, human resource development, rewards, participation, minimum implementation of resources, supervising manner, and organizational structure. Managerial stressors are comprised of role ambiguity, role conflict, workload pressure, quality pressure, job sensitivity, development and promotion, accountability for employees' performance, time pressure, and job-relating technology (Human Resource Management, 2005; Ivancevich et al., 2001). In this research, the effect of two managerial factors on job stress has been investigated: role ambiguity and role conflict. Role conflict occurs when a set of job expectations accepted by a person is in conflict with another set of expectations. As the studies of job stress, researches on work-family conflict have often considered the top managers and white collars (e.g., Grzywacz et al., 2007; Panatik et al., 2012). What the current study examines is the effect of role conflict and role ambiguity in place of work on job stress considering the important role of workfamily conflict. Previous studies have generally investigated and confirmed the relationship between these variables, but the main question and challenge is the type and direction of the relationship between these variables. Therefore, this study is to determine the type and direction of the relationship between role conflict, role ambiguity, work-family conflict, and job stress.

\section{Literature}

\subsection{The effect of role ambiguity on work-family conflict}

Role ambiguity happens when the organization expectations from a job varies with the expectations of customers and people outside the organization, For instance, when the employees encounter with various needs and demands from the customers and the store top managers (Babin \& Boles, 1996). Thus, the role ambiguity is the inseparable part of any work environment (Verbeke et al., 2011), indicating an ambiguous and unreliable work conditions (Cicero et al., 2010), and representing the amount of job simplicity or complexity (Cordery et al., 2010). Most of the researches on role ambiguity are based on Rizzo et al.'s (1970) study, which investigated its various dimensions from various perspectives (e.g., Breaugh \& Colihan, 1994; Li \& Bagger, 2008). In this research, the role ambiguity is investigated from three aspects given the daily affairs that employees encounter: from the supervisors' perspective, managers' perspective, and work ethic.

Kahneman and Lovallo (1993) in their study concluded that the role ambiguity happens because of ambiguous regulations, ethics, and work culture. Role ambiguity is defined as individual's uncertainty degree of job expectations (Baral \& Bhargava, 2010; Epie, 2009; Fayankinnu \& Alo, 2007; Akanji, 2012). According to Verbeke et al. (2011), "when a person does not know exactly what to do he/she may be confused of work or family duties". In other words, it may lead to work-family conflict. Therefore:

\section{$H_{1}$ : Role ambiguity affects the work-family conflict.}

\subsection{The effect of role ambiguity on employees' job stress}

Role ambiguity takes place when a person does not know what he/she should exactly do and is confused with formal and informal situations as well (Schulz \& Auld, 2006). Wall et al. (2002) indicated that the role ambiguity disturbs the job stability and independence. Despite the importance of this issue, few studies have been accomplished surrounding the impact of ambiguity as well as the impact of role ambiguity on various individual and organizational variables (Cordery et al., 2010). One of the important variables, which may be affected by role ambiguity is the employees' job stress 
(Arnold et al., 2009). Psychologists and researchers of management sciences are of great interest in subject of stress and the major reason for this is its effect on psychological well-being and organizational consequences (e.g., Semmer et al., 2005; Jex \& Yankelevich, 2008; Westman, 2001). Cavanaugh et al. (2000) were the first to classify the job stress into two kinds: challenging and preventing stress. They suggested that preventing stress called destructive stress results from factors such as role ambiguity, role uncertainty, and organizational policies, and decreases both the individual and organizational performance, while challenging stress will result in satisfaction, loyalty, trust, and even employees' creativity. According to Tubre and Collins (2000), the individual's role perception has an effect on his/her organizational performance. Furthermore, Harris et al. (2006) concluded that the role conflict and role ambiguity are two influencing factors of job stress. Previous studies have indicated that the role ambiguity had a considerable impact on employees' stress (eg., Arnold et al., 2009; Knight et al., 2007). Therefore:

\section{$\mathrm{H}_{2}$ : Role ambiguity affects the job stress.}

\subsection{The effect of role conflict on work-family conflict}

Role conflict is defined as facing of a person with conflicting expectations. These conflicting and usually unreasonable expectations are generated because of intra- and extra-role conflict. Intra-role conflict is a state that the person should sometimes do conflicting tasks in similar situations, and extra-role conflict also called inter-role conflict, is a state that the person suspects he/she should do a special task while the supervisor or co-workers expect his/her to do a different task (Wallace, 2005).

When a person faces with conflict in his/her job or role, intra-role conflict cause to his/her confusion in distinguishing the boundaries of work and family duties from each other and finally leads to workfamily conflict. Extra-role conflict as well, may be resulted from exposure to the managers and coworkers expectations and family members' expectations and cause to work-family conflict in terms of his/her decisions (Wallace, 2005; Panatik et al., 2012). Therefore:

\section{$H_{3}$ : Role conflict affects the work-family conflict.}

\subsection{The effect of role conflict on employees' job stress}

As mentioned previously, role conflict is one of the most influencing factors of job stress and occurs when at least two conflicting job factor pressures the person (Wu \& Norman, 2006). Rizzo et al. (1970) stated that the role conflict and role ambiguity influences the factors such as job satisfaction and non-functional behavior because of job stress and concerns. In addition, Kelloway and Barling's (1990) reported that role conflict affects the job stress. Therefore:

\section{$\mathrm{H}_{4}$ : Role conflict affects the job stress.}

\subsection{The effect of work-family conflict on employees' job stress}

There have been different definitions for work-family conflict, but of the best definitions is one that is suggested by Greenhaus and Beutell (1985) which is a basis for current study. Many researches reported that the scope of an individual's responsibilities could be in conflict with his/her responsibilities scope in the workplace. This issue is empirically observed in all the individuals' life and usually referred to work-family conflict (Frone et al., 1992; Major \& Germano, 2006). To prevent this issue, we need to identify the stressor factors in and outside of the workplace and determine a certain range for each of the personal, social, and work tasks (Bellavia \& Frone, 2005). 
Work-family conflict is an intra-role and intra-task conflict and happens when various responsibilities of an individual interfere with each other (Greenhaus et al., 1985). In addition, if this type of conflict is not properly managed, it may influence on the other organizational factors such as employees' absenteeism, employees' turnover, organizational commitment, etc. (Frenandez, 1986). Most of the performed researches have considered this conflict from two perspectives: First, the conflict from workplace to family and the other, conflict from family to workplace.

Conflict from workplace to family is the case in which the source of conflict is the workplace and influences the family life. Moreover, conflict from family to workplace is created when the source of conflict is family and family relationships that affect the work aspects of an individual (Frone et al., 1997). Some researches indicate that the work-family conflict has an impact on job stress (e.g., Matthews et al., 2010; Wallace, 2005; Panatik et al., 2012; Hasnain et al., 2012). Panatik et al. (2012) suggested that the work-family conflict influences the job stress. By reviewing the researches on the work-family conflict, it is clear that this kind of conflict is more common between employees who work longer hours or have a more difficult job. Eby et al. (2005) and Poelmans (2001) recommended that the work-family conflict could lead to psychological and nervous pressures of employees. Therefore:

$H_{5}$ : work-family conflict affects the job stress.

\section{Conceptual framework}

Conceptual model of the present study includes the predictor, outcome, and mediator variables (Fig. 1) which were explained in previous section. Meanwhile, the relationships between these variables were investigated according to previous studies.

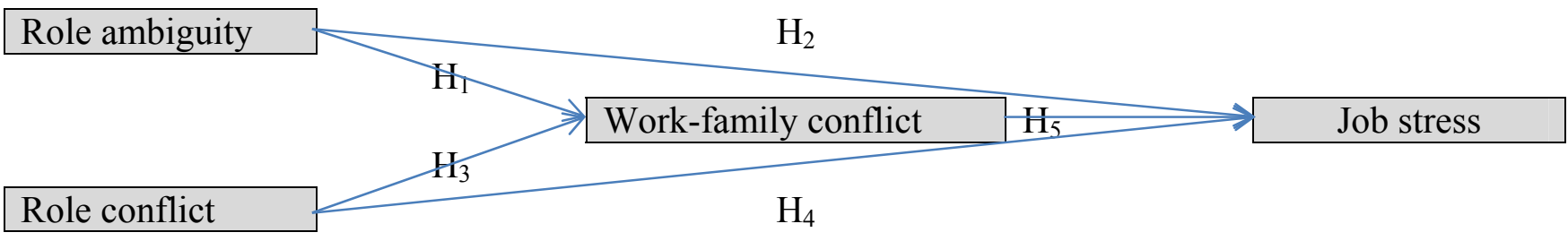

Fig. 1. The proposed study

\section{Research method}

This study is survey in terms of method and is applied-developmental in terms of its objective. The under study population is the employees of Iran's central insurance. A random sampling was applied and the statistical sample was selected using the sampling formula relating to unlimited population (in which $\mathrm{d}=0, \mathrm{Z}=1.96, \mathrm{P}=.5$ ). With a higher percentage, a number of 120 questionnaires were distributed in order to cope with uncompleted questionnaires. In this study, Data gathering tool was questionnaire consisted of employees' general information and 29 specialized questions using 5-point Likert-type scale. The Cronbach's alpha was .88 and split-half reliability was .80 indicating the reliability of questionnaire. In addition, we used content validity and confirmatory factor analysis to confirm the questionnaire validity. In order to analyze the main paths between variables, descriptive statistical methods and structural equation modeling (LISREL software v8.7) were used. In the path analysis method, the path coefficients and relating p-values are calculated and based on its multiplicative rule the direct and indirect effects of each independent variable on dependent variable are calculated. Variables of the conceptual model in terms of the number of their questions and their Cronbach's alpha are provided in Table 1. 
Table 1

Research variables (The number of items and Cronbach's alpha)

\begin{tabular}{lcc}
\hline \multicolumn{1}{c}{ variable } & Number of items & Reliability (alpha) \\
\hline role ambiguity & 6 & .803 \\
role conflict & 8 & .789 \\
work-family conflict & 7 & .89 \\
job stress & 8 & .760 \\
\hline Total & 29 & .880 \\
\hline
\end{tabular}

\section{Findings}

In this section, we are to explain the statistical analyses of structural equation modeling with the path analysis approach in addition to study the participants' demographics. To do so, the participants' demographics including gender, age, organizational tenure, and education level are provided in table 2. In our study, 70 people were male and 45 people were female. Fig. 2 demonstrates other personal characteristics of the participants.

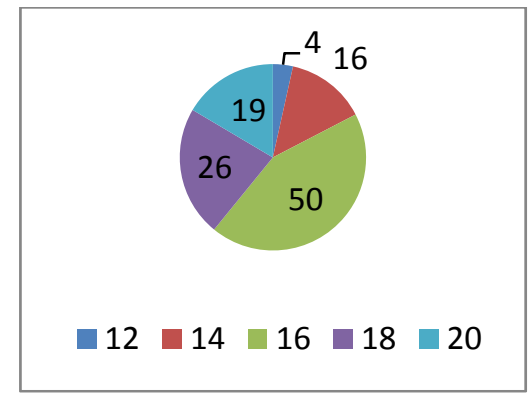

Years of educational background

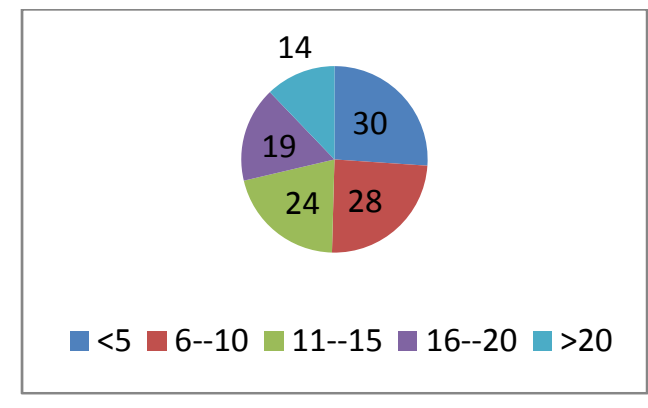

Years of job experiences

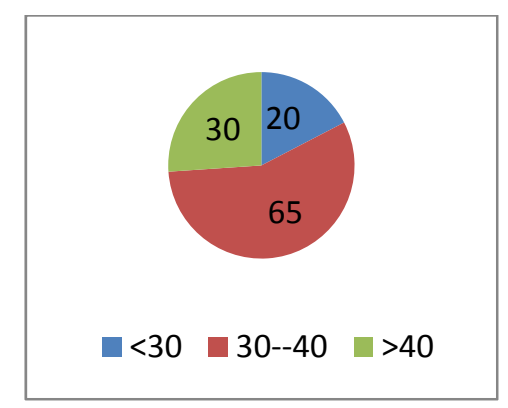

Age

Fig. 2. Personal characteristics of the participants

\subsection{Analyzing the hypotheses using path analysis approach}

\subsubsection{Estimating and evaluating the path model using structural equation modeling}

In this section, the structural equation modeling was conducted in order to test the causal relationships between role ambiguity, role conflict, work-family conflict, and job stress. The proposed hypotheses in the form of research conceptual model are indicated in Fig. 3 using the path analysis approach. The standard research model along with path coefficients relating to each relationship can be seen in this figure. Note that "ebhamnag" represents role ambiguity, "taoruzka" stands for work family conflict, "taoruzna" is for role conflict and "esterssh" describes job stress.

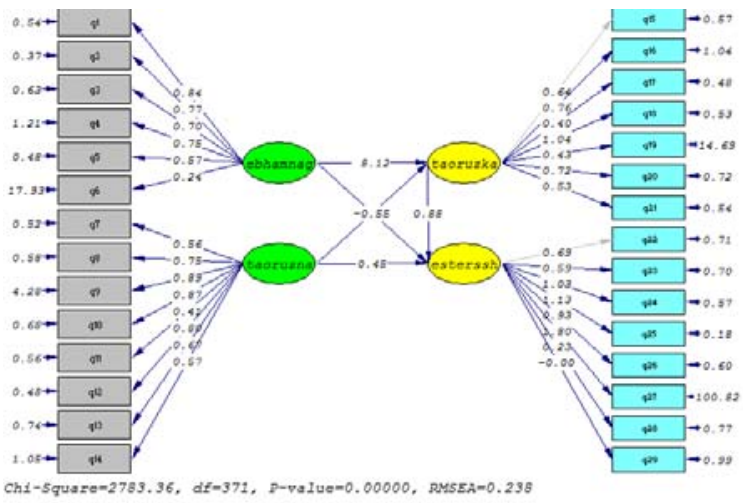

Fig. 3. Model estimation and path coefficients existing between variables

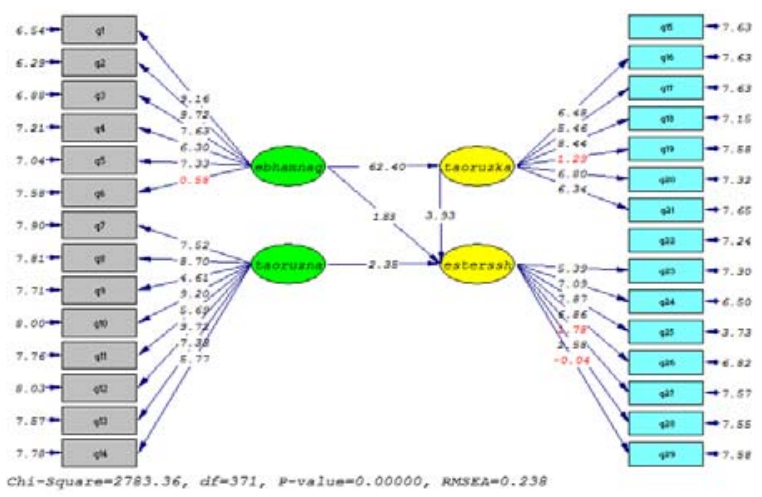

Fig. 4. Model significance test and determining the confirmed paths based on structural equation modeling 
Now, the significance values of the relationship between variables should be considered in order to test the research hypotheses and ensure the obtained coefficients to affect the variables on each other (these values are provided in Fig. 4). On the other hand, research hypotheses are investigated based on their standard estimation and their respective significance values.

Table 2

Testing research hypotheses

\begin{tabular}{clccc}
\hline \multirow{2}{*}{ Hypotheses } & \multicolumn{1}{c}{ Path } & $\begin{array}{c}\text { Standard } \\
\text { estimation }\end{array}$ & t-value & Result \\
\hline 1 & Role ambiguity affects the work-family conflict. & 8.12 & 62.40 & confirmed \\
2 & Role ambiguity affects the job stress. & -0.55 & 1.83 & confirmed \\
3 & Role conflict affects the work-family conflict & -0.55 & & rejected \\
4 & Role conflict affects the job stress & 0.45 & 2.35 & confirmed \\
5 & work-family conflict affects the job stress & 0.88 & 3.93 & confirmed \\
\hline
\end{tabular}

It should be noted that if the significance values are greater than 1.96 the path significance of the relationships are confirmed. On this basis, the hypotheses number 1, 2, 4, and 5 are confirmed and the hypothesis number 3 is rejected. These results indicate that the ambiguity affects the formal job roles and informal family roles affect the work-family conflict.

In addition, the work-family conflict results in job stress, while the role ambiguity itself leads to job stress directly. In this research, the effect of role conflict on the work-family conflict was not confirmed indicating that inconsistency between various job expectations does not so affect the workfamily conflict. However, like the role ambiguity, the role conflict can leads to job stress and affect the employees' performance and efficiency.

\subsubsection{Model fit indices}

In the Lisrel software, in addition to estimation of model coefficients and errors some indices are reported which accordingly the model overall fitness is evaluated. Some people emphasized three fundamental criteria for evaluating the absolute model fit: the chi-square likelihood ratio $\left(\mathrm{x}^{2} / \mathrm{df}\right)$, goodness of fit index (GFI), and root mean squared error of approximation (RMSEA). These mentioned indicators are reported in Table 3. As it can be seen, most of the indicators are greater than standard values and represent for a good model fit to data.

Table 3

Model fit indices

\begin{tabular}{ccc}
\hline goodness of fit indices & $\begin{array}{c}\text { Model fitness } \\
\text { Desired value }\end{array}$ & results \\
\hline$x^{2} / d f$ & $<3.00$ & 7.11 \\
GFI & $>0.85$ & 0.98 \\
RMSEA & $<0.08$ & 0.238 \\
RMR & $<0.05$ & 0.043 \\
NFI & $>0.90$ & 0.91 \\
NNFI & $>0.90$ & 0.91 \\
CFI & $>0.90$ & 0.93 \\
\hline
\end{tabular}




\section{Discussion and Conclusion}

After explaining the variables such as role ambiguity, role conflict, work-family conflict, and job stress, we are to investigate the effect of role ambiguity and role conflict on work-family conflict and stress, and finally the effect of work-family conflict on job stress. In order to achieve this goal, related literature was investigated and finally, research conceptual framework was designed. In the following, research hypotheses were examined based on the assumed relationships of the model. In order to test the hypotheses, research data was analyzed using statistical techniques mentioned in the findings section and following results were obtained:

The first and the second hypotheses expressing the effect of role ambiguity on work-family conflict and job stress were confirmed. This result is consistent with the studies of Tubre and Collins (2000), Tuten and Neidermeyer (2004), Jackson and Schuler (1985), and Boles and Babin (1996).

The third hypothesis reflecting the effect of role conflict on work-family conflict was investigated and not confirmed contrary to studies of Wallace (2005), Panatik et al. (2012), and Boles and Babin (1996).

The forth hypothesis representing the effect of job conflict on job stress was confirmed too. This result is consistent with the studies of Wallace (2005), Panatik et al. (2012), and Boles and Babin (1996). The effect of work-family conflict on job stress was investigated in the fifth hypothesis and was confirmed, which is consistent with the studies of Matthews et al. (2010), Wallace (2005), Panatik et al. (2012), and Hasnain et al. (2012).

In general, it can be concluded that in job environments associated with role ambiguity because of unclear job description and organizational chart and those environments that are informal, the most work-family conflict and stress is experienced. On the other hand, role conflict, which is occurred due to interference of a person's different roles in the organization and family, has greater effect on job stress. Finally, if the occurred work-family conflict emanated from role ambiguity and role conflict is not managed properly and individual is not supported by his/her family and supervisors, job stress affects his/her performance destructively.

\section{References}

Acker, J. (1998). The future of 'gender and organizations': connections and boundaries. Gender, Work \& Organization, 5(4), 195-206.

Akanji, B. (2013). Realities of Work Life Balance in Nigeria: Perceptions of Role Conflict and Coping Beliefs. Business, Management and Education, 10(2), 248-263.

Arnold, T., Flaherty, K. E., Voss, K. E., \& Mowen, J. C. (2009). Role stressors and retail performance: the role of perceived competitive climate. Journal of Retailing, 85(2), 194-205.

Babin, B. J., \& Boles, J. S. (1996). The effects of perceived co-worker involvement and supervisor support on service provider role stress, performance and job satisfaction. Journal of retailing, 72(1), 57-75.

Baral, R., \& Bhargava, S. (2010). Work-family enrichment as a mediator between organizational interventions for work-life balance and job outcomes, Journal of Managerial Psychology 25(3), 274-300.

Bellavia, G. M., \& Frone, M. R. (2005). Work-family conflict. In J. Barling, E. K. Kelloway, \& M. R. Frone (Eds.), Handbook of work stress (pp. 113-147). Thousand Oaks, CA: Sage.

Boles, J. S., \& Babin, B. J. (1996). On the front lines: Stress, conflict, and the customer service provider. Journal of Business Research, 37(1), 41-50. 
Breaugh, J. A., \& Colihan, J. P. (1994). Measuring facets of job ambiguity: Construct validity evidence. Journal of Applied Psychology, 79, 191-202.

Brinkman, R. (2002). Dealing with People You Can't Stand: How to Bring Out the Best in People at Their Worst. McGraw-Hill, New York.

Cavanaugh, M.A., Boswell, W.R., Roehling, M.V., \& Boudreau, J.W. (2000). An empirical examination of self-reported work stress among U.S. managers. Journal of Applied Psychology, 1, $65-74$.

Cicero, L., Pierro, A., \& van Knippenberg, D. (2010). Leadership and uncertainty: How role ambiguity affects the relationship between leader group prototypicality and leadership effectiveness. British Journal of Management, 21, 411-421.

Cook, J. D., Hepworth, S. J., Wall, T. D., \& Warr, P. B. (1981). Experience of work: A compendium and review of 249 measures and their use. New York: Academic Press.

Cordery, J. L., Morrison, D., Wright, B. M., \& Wall, T. D. (2010). The impact of autonomy and task uncertainty on team performance: A longitudinal field study. Journal of Organizational Behavior, 31, 240-258.

Dua, J. K. (1994). Job stressors and their effects on physical health, emotional health and job satisfaction in a university. Journal of Educational Administration, 32(1), 59-78.

Eby, L. T., Casper, W. J., Lockwood, A., Bordeaux, C., \& Brinley, A. (2005). Work and family research in IO/OB: Content analysis and review of the literature (1980-2002). Journal of Vocational Behavior, 66(1), 124-197.

Epie, C. (2009). Managing time-based conflict across life domains in Nigeria: A decision making perspective. Ife Psychological, 17, 194-216.

Fayankinnu, E. A., \& Alo, O. A. (2007). Globalization and work: An insight from the Ghanaian and Nigerian women experience, Gender and Behaviour, 5(1), 1129-1161.

Fernandez, J. P. (1986). Child care and corporate productivity: Resolving family/work conflicts. Lexington, MA: Lexington Books.

Frone, M. R., Russell, M., \& Cooper, M. L. (1992). Antecedents and outcomes of work-family conflict: Testing a model of the work-family interface. Journal of Applied Psychology, 77, 65-78.

Frone, M. R., Yardley, J. K., \& Markel, K. S. (1997). Developing and testing an integrative model of the work-family interface. Journal of Vocational Behavior,50(2), 145-167.

Glass, J. (2004). Blessing or curse? Work-family policies and mother's wage growth over time. Work and Occupations, 31(3), 367-394.

Gordon, J. R., Whelan-Berry, K. S., \& Hamilton, E. A. (2007). The relationship among work-family conflict and enhancement, organizational work-family culture, and work outcomes for older working women. Journal of Occupational Health Psychology, 12, 350-364.

Gordon, M. D. (1981). The dissemination strategies of researchers working in the field of health and personal social services. Social Science Information Studies, 1(5), 307-316.

Greenhaus, J. H., \& Beutell, N. J. (1985). Sources of conflict between work and family roles. Academy of management review, 10, 76-88.

Greenhaus, J. H., \& Beutell, N. J. (1985). Sources of conflict between work and family roles. Academy of management review, 76-88.

Grzywacz, J. G., Frone, M. R., Brewer, C. S., \& Kovner, C. T. (2006). Quantifying work-family conflict among registered nurses. Research in nursing \& health, 29(5), 414-426.

Harris, E. G., Artis, A. B., Walters, J. H., \& Licata, J. W. (2006). Role stressors, service worker job resourcefulness, and job outcomes: An empirical analysis. Journal of Business Research, 59(4), 407-415.

Harrisons, B. (2005). Principles of International Medicine. American: New York \& Sons. LTD.

Hasnain, N., Ansari, S.A., Ali, SH., Sharma, S.,(2012), Work-family conflict and occupational stress as correlates of life satisfaction among male and female managers. International Review of Business and Social Sciences, 1(9), 1-10.

Human Resource Management. (2005). Occupational Stress. www.HRMguide.Co.uk 
Jackson, S. E., \& Schuler, R. S. (1985). A meta-analysis and conceptual critique of research on role ambiguity and role conflict in work settings. Organizational Behavior and Human Decision Processes, 36(1), 16-78.

Jamal, M. (1990). Relationships of job stress and Type A behavior to employees' job satisfaction, organizational commitment, psychosomatic health problems, and turnover motivation. Human Relations, 43(8), 727-738.

Jex, S. M., \& Yankelevich, M. (2008). Work stress. In J. Barling, \& C. L. Cooper (Eds.), The Sage Handbook of Organizational Behavior, 1. (pp. 498-518)Los Angeles: Sage.

Grzywacz, J. G., Arcury, T. A., Marín, A., Carrillo, L., Burke, B., Coates, M. L., \& Quandt, S. A. (2007). Work-family conflict: Experiences and health implications among immigrant Latinos. Journal of Applied Psychology, 92(4), 1119-1130.

Kahneman, D., \& Lovallo, D. (1993). Timid choices and bold forecasts: A cognitive perspective on risk taking. Management Science, 39(1), 17-31.

Kelloway, E. K. \& Barling, J. (1990). Item content versus item wording: disentangling role conflict and role ambiguity. Journal of Applied Psychology. 75(6), 738-742.

Knight, D. K., Kim, H. J., \& Crutsinger, C. (2007). Examining the effects of role stress on customer orientation and job performance of retail salespeople.International Journal of Retail \& Distribution Management, 35(5), 381-392.

Li, A., \& Bagger, J. (2008). Role ambiguity and self-efficacy: The moderating effects of goal orientation and procedural justice. Journal of Vocational Behavior, 73(3), 368-375.

Major, D. A., \& Germano, L. M. (2006). The changing nature of work and its impact on the workhome interface. In F. J. Jones, R. J. Burke, \& M. Westman (Eds.), Work-life balance: A phychological perspective (pp. 1-38). New York: Psychological Press.

Matthews, R.A., Bulger, C.A., Barnes-Farrell, J.L., (2010), Work social supports, role stressors, and work-family conflict:The moderating effect of age. Journal of Vocational Behavior, 76 , 78-90

Panatik, S. A. B., Rajab, A., Shah, I. M., Rahman, H. A., Yusoff, R. M., \& Badri, S. K. B. Z. WorkFamily Conflict, Stress and Psychological Strain in Higher Education.

Poelmans, S. (2001). Work family conflict as the mediator of the work stress- mental health relationship, in Research paper University of Navarra. University of Navarra: Spain.

Rizzo, J. R., House, R. J., \& Lirtzman, S. I. (1970). Role conflict and ambiguity in complex organizations. Administrative science quarterly, 150-163.

Schulz, J., \& Auld, C. (2006). Perceptions of Role Ambiguity by Chairpersons and Executive Directors in Queensland Sporting Organisations. Sport Management Review, 9, 183-201

Semmer, N. K., McGrath, J. E., \& Beehr, T. A. (2005). Conceptual issues in research on stress and health. In C. L. Cooper (Ed.), Handbook of stress medicine and health (pp. 1-43). (Second ed.). London: CRC Press.

Tang, Y. T., \& Chang, C. H. (2010). Impact of role ambiguity and role conflict on employee creativity. African Journal of Business Management, 4(6), 869-881.

Tubre, T. C., \& Collins, J. M. (2000). Jackson and Schuler (1985) revisited: A meta-analysis of the relationships between role ambiguity, role conflict, and job performance. Journal of Management, 26(1), 155-169.

Tuten, T. L., \& Neidermeyer, P. E. (2004). Performance, satisfaction and turnover in call centers: The effects of stress and optimism. Journal of Business Research, 57(1), 26-34.

Verbeke, W., Dietz, B., \& Verwaal, E. (2011). Drivers of sales performance: a contemporary metaanalysis. Have salespeople become knowledge brokers?.Journal of the Academy of Marketing Science, 39(3), 407-428.

Wall, T., Cordery, J. L., \& Clegg, C. (2002). Empowerment, performance and operational uncertainty: A theoretical integration. Applied Psychology-An International Review, 51, 146149.

Wallace, J.E. (2005). Job Stress, Depression and Work-to-Family Conflict: A Test of the Strain and Buffer Hypotheses. Relations industrielles / Industrial Relations, 60(3), 510-539. 
Westman, M. (2001). Stress and Strain Crossover. Human Relations, 54, 717-751.

Wu, L., \& Norman, I. J. (2006). An investigation of job satisfaction, organizational commitment and role conflict and ambiguity in a sample of Chinese undergraduate nursing students. Nurse Education Today, 26(4), 304. 